Financial Markets, Institutions and Risks, Volume 3, Issue 4, 2019 ISSN (online) - 2521-1242 ISSN (print) - 2521-1250

\title{
Impact of Value Added Tax on Business Enterprises: A Case of Mettu Town
}

S.N. Singh, ORCID: http://orcid.org/0000-0002-1494-4489

Dr, Associate Professor of Economics and Law in the Department of Economics, Faculty of Business and Economics, Mettu University, Mettu, Ethiopia

\begin{abstract}
This paper summarizes the arguments and counterarguments within the scientific discussion on the issues of impact of value added tax on business enterprises. The main purpose of the research is to examine the impact of value addition tax on business enterprises in Ethiopia particularly in Mettu Town of Oromia region. The other specific objectives are to examine how value addition tax influences the private investment in enterprises, to examine the major other factors that are responsible for low business investment in Mettu town of Ethiopia. Systematization literary sources and approaches for solving the problem have widely been used that indicates that there is a contradictory scalier on impact of VAT on business entrepreneurship's investment in Ethiopia. The relevance of the decision of this scientific problem is that how implication of value addition tax affecting the business activities. Investigation of the topic mentioned above is carried out in the following logical sequence measuring value addition tax; expansion or contraction of business enterprises in Ethiopia. Methodological tools of the research methods were comparative analysis using statistical tools and techniques for the years of research 2017-18. The object of research is the regions specified systematically, because namely they were elaborated. The paper presents the results of an empirical analysis of impact of value addition tax on business enterprises, which showed that there is a contradictory paradox among parameters. The research empirically confirms and theoretically proves that the value addition tax has the partial impact on the investment in business enterprises and other factors are responsible for investment in business enterprises in Ethiopia. The results of the research can be useful for Policy maker, academicians and researchers.
\end{abstract}

Keywords: Value Added Tax, Business Enterprises, Expansion and contraction.

JEL Classification: H25, H29.

Cite as: Singh, S.N. (2019). Impact of Value Added Tax on Business Enterprises: A Case of Mettu Town. Financial Markets, Institutions and Risks, 3(4), 62-73. http://doi.org/ 10.21272/ fmir.3(4). 62-73.2019

(C) The Authors, 2019. This article is published with open access at Sumy State University.

\subsection{Introduction}

\subsection{Background of the Study}

Taxation is the system of raising money to finance government services and activities. Government at all levels local, state, and national require people and business to pay taxes. Governments use the tax revenue to pay the cost and policy and fire protection health programs, schools, roads national defense and many other public services. At the 9th VADA (Value Added Tax Administration in Africa) Forum Ethiopian delegates (2006) in Zimbabwe also emphasized that the Ethiopian VAT is a federal tax to be administered centrally.

The general level of taxes has various through the years, depending on the role of the government. Now a day, many governments especially in advanced industrial countries have rapidly expanded their roles and taken on new responsibilities. As a result, their need for tax revenue has become great. (World book encyclopedia volume 19). Through the years, people have frequently protested against tax increases. In these situations, tax payers have favored keeping services at current level or reducing those voters has defeated many proposals for tax increase by state and local government. Governments levy many kinds of taxes and classify them into two groups called direct taxes and indirect taxes, property taxes and income taxes are said to be direct taxes, and taxes on transaction is grouped under indirect taxes, (Gebre, 2006). Simply adopting a successful VAT's design attributes of developed countries would not make the tax successful (Bird and Gendron 2005).

Property taxes are levied on the value of such property as firms, house, stores, factories and business equipment. Income $t$ axes are levied on income from such sources as wages, and salaries, dividends, interest rent, and earning of corporations. There are two main types of income taxes. They are individual income taxes and corporate income taxes. Taxes on transaction are levied on sales of goods and services on privileges. There are three main types: General sales taxes, excise taxes, and tariffs, (Misrak, 2008). 
Financial Markets, Institutions and Risks, Volume 3, Issue 4, 2019 ISSN (online) - 2521-1242 ISSN (print) - 2521-1250

As Bird (2005) noted the existence of a fundamental gap between the institutional requirements for a good VAT administration and the real fiscal institutions in place in a country is one of the factors contributing to the poor and unfair performance of VAT. General sales taxes apply one rate to the sales of many different items. Such taxes include state sales tax and general sales taxes in different countries, Such as United States and Canada. It is applied to increase in the value of a product at each stage in the manufacture and distribution. The value added tax was paid by every company that handles a product during its transaction form raw materials to finished goods. The amount of tax was determined by the amount of value that a company adds to the materials and services it buys from other firms, (Arega, 2004)

Another argument was that a value added tax was a fairly simple method of collecting substantial revenues, which would lead to substantial saving for tax authorities. The most common way to operate a VAT was to tax Goods as they travel among stages of production. By taxing the value added at each stage, the final value of the good was eventually taxed, (Alan, 2001). The key to the VAT was that invoices are credited at each production stage. Firms are liable only for the difference between VAT paid on purchases and VAT charged on sales. Invoice keeps tax of which credits firms are allowed. Firms subtract that VAT paid on purchases (the credit) since it presents the tax liability in the previous stage of production. Taxes are therefore collected only on value added at each stage of production. VAT was a modified sales tax based on the net value added at each stage rather than on grow. In Ethiopia the autonomous body to collect tax was the Federal Inland Revenue Authority (FIRA). The Minister of finance and economic planning, in his budget speech for the financial year 2001/02 announced that government would introduce VAT system was effect form Jan 1, 2003 to replace the existing sales Tax under proclamation number 285/2001-2. Omokahuale and Immanuela (2016) noted, Nigeria improving tax related services by tax authority particularly on VAT refund request verification activities, were based on computer system in order to improve trade facilitation and tax management to their business in the economy.

Ethiopia was the last to implement VAT among 33 African countries like Uganda (1996), Kenya (1990), Sudan (2002) and South Africa (1991).(---African countries with VAT, FIRA unpublished). In Ethiopia the law forces all governmental organization to buy from registered firms if their purchase amount was beyond 500,000 birrs. This will force eligible firms to be registered. In Ethiopia the standard VAT rate was 15 percent and the threshold of annual sales should be greater than 500,000-birr individuals whose annual sale were less than the threshold can also register for VAT was their 75 percent transaction was with registered companies. (Negarit Gazeta, 2004). Cottarelli (2011) noted, experience in Zambia a robust refund mechanism was introduced in 2005 , and financing of refunds has been ring-fenced, based on returns submitted by the end of one month, and is made from gross VAT (domestic and import) collections in the following month, before the net balance is transferred to the Treasury. Zerihun (2016) noted, the economy has been growing at a remarkable rate at an average more than 10 percent, the slow growth in the tax to GDP ratio suggests the growth in tax collection is not proportionate with the economic growth perhaps indicating a huge untaxed potential.

VAT was introduced in Ethiopia apart of fiscal policy with some objectives. The objectives ofVAT implementation in Ethiopia are to enhance economic growth, improve the relationship between GDP \& government revenue. It also improve saving and investment.Lastly to maximize government revenue(Yohanes \& Sisay,2009). It is collected on business transaction and imports. Most business transaction involve supplies of goods or service and VAT is payable if they are supplies made in Ethiopia, made by a taxable person, made in the course of furtherance of a business are not specifically exempted of zero - rated (Gebrie, 2008)

There is a research conducted on this study from Agernew Tefera explains the existing sales tax.According to this researcher 70 percent of business people prefer VAT than sales tax but they remark "If it was implemented properly \& adequately". But at current situation it was not preferable since FIRA doesnot undertake easy tax collection system.(Yohanes \& Sisay,2009). We understood the structure of VAT, like a sales tax, VAT, can also be designed to have different forms, exemption and rates. In this connection, there are two important varieties of VAT, they are: the consumption varieties and the income variety. The difference between these two varieties emerges from the treatment of capital depreciation. If the firms are allowed to deduct the entire credit when the capital equipment is purchased, the system is termed as consumption VAT. If the firms are allowed to deduct the credit as the equipment depreciates overtime, the system is termed as an income VAT, Yohannes and Sisay, 2009).

\subsection{Statement of the problem}

Most taxpayers make complaints that the system is not implemented efficiently. There are so many business people operate without registration. This shows there was a problem in between them. Currently in Ethiopia, 
Financial Markets, Institutions and Risks, Volume 3, Issue 4, 2019

ISSN (online) - 2521-1242 ISSN (print) - 2521-1250

it was estimated that 15, 000 business people are eligible to value added tax but until January 1, 2004, only 7,200 business people were registered. These shows nearly 50 percent were not registered due to lack of awareness or sales are greater than or equal to 500,000 Birr, were found unregistered during door to door assessment by Federal Inland Revenue Authority (FIRA) (fortune news paper, 2003). It's estimated that there are more than four hundred businesses those are eligible to VAT, but only $47 \%$ of them registered for VAT in Mettu town. Problem arises from point of view of tax administers on one side tax payers on the other side. These problems differ from tax payers to tax payers. Therefore, this study focuses on these two groups. This helps to understand the real problems with regard to the implementation of the system to make the awareness of the tax payment to business holders to increase government revenue.

\subsection{Objective of the study}

1.3.1 General objectives. The general objective of the study is to assess the impact of VAT on business enterprises.

\subsubsection{The specific objectives of the study are}

1. To determine whether Value Added tax has an impact on the pricing of goods on a business enterprise.

2. To assess whether VAT has impact on sales of goods on small business.

3. To assess awareness of tax among the small business owners.

\subsection{Research Question}

1. What are the impacts of VAT on small business enterprises?

2. What are the reasons of small business not registered for VAT?

3. Are tax payers aware about value added tax?

1.5 Significance of the study. The study focuses on the Value Added Tax and its impact on business enterprises. The outcome of this study is useful for the owners of the business as well as the governments.

Generally, the study is believing to have information for business owner about the impact of value Added Tax on the business. It gives information for the governments about the drawback of the system, and to suggest some possible solution to solve impact of VAT on business enterprises.

1.7 Limitation of the Study. This research is conduct by carefully giving its due consideration, and every effort denote to make the research effective. However, due to some inconvenience departure from accuracy is exhibit. The research is limit to:

- $\quad$ The skill in the operation of computer to analyze the research result.

- The willingness of the respondents to give information related to taxes and its impact on the business enterprises.

\subsection{Literature Review}

2.1 Theoretical Literature. The introduction of the VAT was probably the most important tax developments in the world. VAT had been introduced for the first time almost 50 years ago, and its application remained confined to handful of countries until the late 1960's. Today VAT was applied in over 120 countries. This makes about 4 billion people or 70 percent of the world's populations live in countries with VAT. In this countries VAT raised about $\$ 18$ trillion in tax revenue, roughly a quarter of all governments' revenue. In Ethiopia form December 1995 E.C up to December 1996 E.C. Vat raises about 1 billion birrs. This figure increases the government revenue by more than 10 parentages. If the system was implemented properly, the contribution to the total government revenue would increase at alarming rate, (Gupta, 2001). The federal Democratic republic of Ethiopia recently has joined the over 120 countries of the world that have already adopted VAT into their tax system. VAT was introduced in Ethiopia apart of physical policy with those following objectives. The objectives of VAT implementation in Ethiopia as part of physical policy are to enhance economic growth and improve the ratio relationship between GDP and government revenue. It also improves saving and investment as it was essentially a consumption tax and does not capital tax. Lastly to maximize government Revenue, (Yohanes and Sisay, 2009). 
Financial Markets, Institutions and Risks, Volume 3, Issue 4, 2019 ISSN (online) - 2521-1242 ISSN (print) - 2521-1250

The law with regards to the VAT requires the following person to pay value added tax if it was a person who was registered or required to be registered, A person carrying out taxable import of goods and with respect to VAT, and A non-resident person who performs services without registration for VAT who was subject to reserve on change taxation with respect to such services, (Arega, 2004). A person who was registered was taxable as soon as registration for VAT takes place. But a person who fails to adhere to registration requirements considered to be taxable beginning from the start of the accounting period following the period to the obligation for registration arose, (Negarit Gazette, 2002).

A research conducted by Agernew Tefera Explains the existing sales tax. According to his finding 70 percent of business people prefer VAT than sales tax but they remark, "If it was implemented properly and adequately". But at current situation it was not preferable since FIRA does not undertake easy tax collection system and was concerned only the appropriate amount of tax to be paid. And most of them suggest that some sort of items should be free of VAT and the authority should create awareness not only to the business people but also for the society at large. (Comparison of existing sales tax with the new tax system VAT, (Agernew, 1995). Value added tax (VAT) belongs to the family of sales taxes. Therefore, it would be helpful if we briefly distinguish between different forms of sales taxes and note the place of VAT in them. A general sales tax is a tax on sale transactions, but it is applied at only one stage of business activity right from the manufacturer to the retailer. Usually it was collected either at the whole sale level at a retail level. The traders are allotted sales tax numbers and trader possessing such a number can purchase are the goods without paying the sale tax. He similarly sells the goods to the next buyers net of sales tax if the next tax happens to possess a sales tax number. Otherwise, he charges the sales tax was the turnover tax. While the former tax is imposed only at one point of sale, turnover tax was imposed at each sales transaction. A good, therefore, was subjected to as many tax levies are the transaction through which it passes. Consequently, a turnover tax tends to increase the final sale volume to the consumer cumulatively. In order to secure competitive advantage over others, the forms try to go in for vertical integration and thus turnover taxes on intermediate sales. This encourages turnover taxes on intermediate sales. This encourages monopolistic tendencies. (HL Bhatia, 1998).

VAT was a tax not on the total value of the good sold, but only on the value added to it by the last seller. The seller therefore was liable to pay a tax not on its gross value, but net value, that is the gross value minus the value on inputs. The basic difference between VAT and sales tax was that the tax liability under VAT was split up into stages. Theoretically, the tax liability in the case of Vat and in the case of sales tax at the retail level should turn out to be the same. This is because the total retail price is nothing, but the value added to the raw materials at different stages of production and trade. In the case of VAT, the same total of created value was taxed in stages. The usual practice is to estimate the tax liability of the last seller on the basis of gross value of the producer and give him credit for the taxes paid by the earlier sellers. It must be noted that, here, the assumptions that final sale value at retail level presents the actual value added at different stages and that the market friction and other imperfections are not distorting the whole picture, (Dr. Ramswami, 2005)

The differential incidence of the retail sale tax and the value added tax consumption type was nil, because both taxes have the same aggregate base. The consumptions tax (retail sales tax) was imposed on the amount consumers pay (ex. Other tax, if any) for consumption goods, paid to factors for producing those goods. These remarks, of course abstract from friction and the imperfection in the marker. But a basic difference between a sales tax and VAT which must be emphasized was that base of VAT "was not the gross value of the retail sale but rather the net value added at each stage of production". And that it distinguishes it from a turnover tax also where each transaction is taxed on its gross value, (Gupta, 2004).

\subsection{Empirical Literature}

\section{Forms of VAT}

Like a sales tax, VAT can also be designed to have different forms, exemption and rates. In this connection, there are two important varieties of VAT, they are: the consumption varieties and the income variety. The difference between these two varieties emerges from the treatment of capital depreciation. If the firms are allowed to deduct the entire credit when the capital equipment is purchased, the system is termed as consumption VAT. If the firms are allowed to deduct the credit as the equipment depreciates overtime, the system is termed as an income VAT, Yohannes and Sisay, 2009)

\section{Distinguishes between four possible varieties of VAT}

1. The first variety was the production VAT: in this case to arrive at the valued added by a firm, the value of the inputs purchased by it from other firms was not deducted in full. Only the value of non-capital purchases 
Financial Markets, Institutions and Risks, Volume 3, Issue 4, 2019

ISSN (online) - 2521-1242 ISSN (print) - 2521-1250

was deducted. Furthermore, no depreciation was permitted on the purchase of capital goods even in subsequent years. Thus, the value added by a firm was taken to be inclusive of the use of capital goods even when they have been purchased from other firms. For the economy as a whole, the value added, calculated in this way, becomes equal to the gross national product) if there was no foreign trade). Therefore, the value Added tax for the country may as a whole also becomes the gross national products (GNP). This variety may be termed production VAT. In simple words, the tax base for any firms will be just sales minus materials (other than capitals goods). This type of VAT, obviously, cannot be popular with the governments, because it militates against the use of capital and retards economic growth

2. The second variety is the consumption VAT: - in this case, the firms was question allowed to deduct from the gross value of its product not the non -capital imputes purchased from other firms, but also the capital equipment so purchased. In the absence of foreign trade, the aggregate base of this tax for the economy as a whole, becomes wages (w) plus profits (p), plus depreciation (D) minus investment (I), now since GNP is equal to $\mathrm{W}+\mathrm{P}+\mathrm{D}=$ consumption $(\mathrm{C})+$ investment $(\mathrm{I})$, therefore, the aggregate tax base becomes GNP-I that is consumption in the economy. All the European countries which have adopted VAT have chosen the consumption variety. One reason for this was that if the firms are allowed depreciation on capital equipment, they tend to apply a high rate of deprecation. "The definition of value-added net of all fixed capital purchase instead of net of depression was, of course illogical but deliberate. It aims at correcting the basis against faster scraping and mechanization". Also, such a tax base is simple to estimate. Winfrey uses a simple way of presenting this variety of VAT, namely 'sales proceeds minus capital minus materials.

3. The thirds variety was the one where the firm was able to deduct the earning forms its capital in order to arrive at the tax base. Since earnings from capital amount to profits plus interest, therefore, the balance left to be taxed is equivalent to wages. Therefore, this variety of VAT was called the wages-type VAT. And it was also unlikely to be used for taxation by any government.

4. The fourth variety was where the firm was allowed to deduct the full value of its non-capital purchases from other firms and depression on the capital-purchases from other firms. This approach obviously gives us the proper net value added. For the country as whole the aggregate tax base (in the absence of international trade) would be that net national product (NNP). This was called the income type VAT. In other words, here, the tax, bases were sales minus materials minus depreciation for each form. The income variety was the most complicated of all the variety through logically it has a greater appeal.

\subsection{Methodology}

3.1 Description of the study Area. The study is conduct mainly in Oromia region, which has large territorial boundary and around 45 million populations are there. Oromia has very attractive region for different activities as well as for survival specially, she has ever green natural resources and there is a suitable weather condition, and in Ilubabor Zone Particularly in Mettu town. Mettu is located in south western part of Ethiopia at the distance of $600 \mathrm{Kms}$ from the capital city of Ethiopia which is Addis Ababa. It's bordered on the south by Ale, on the southwest by Bure,on the west by Qelam Wollega Zone, on the north by Darimu,in the east by Yayo.Demographically,Mettu has total population of 135,231 of whom 72976 are men and 62255 are women.The Town has tropical climate and very attractive weather condition is there for live. The Average annual rainfall of Mettu Town is $1701 \mathrm{~mm}$. The average annual Temperature is at high $20 \mathrm{C}^{\mathbf{o}}$ and at lower $19 \mathrm{C}^{\mathbf{o}}$.

\subsection{Types and Source of Data}

To conduct the objectives of the study, the researcher uses both primary data and secondary data. They are obtained from primary and secondary sources of data. Primary data is collected from the view and opinion of employee of the Inland Revenue Authority that means through interview, questionnaire and the owners of small business. Secondary data is collected from official documents, books and records to relate to the case under the study.

\subsection{Methods of Data Collection}

The researcher uses different types of data collection in the study. The data collection methods varied according to the source of data collection. The researcher uses questionnaire and interview to collect primary data. Questionnaire is fill by taxpayer business owner. And interview is to tax authorities.

Questionnaire method of data collection plays a great role for the collection of motives, feeling of the respondents about the subject under the detail. The questions are carefully analyzed, discuss and conclusion is 
Financial Markets, Institutions and Risks, Volume 3, Issue 4, 2019 ISSN (online) - 2521-1242 ISSN (print) - 2521-1250

achieved. The format of questions of the questionnaire is from general to particular. The questionnaires discuss in such a way that the objective of the study is easily access and investigate in detail.

The respondents of the questionnaire are Inland Tax Authorities office employee and people that own the business. Secondary data is also use in the study to explain the above. The secondary data is collected from certain proclamation about the taxes, some important article, policies and procedures of taxes those who have experience by the Inland Revenue Authority.

\subsection{Sample Techniques and Sample Size}

Judgment sampling is use for the selection of samples. The judgment is use on nature of enterprises (private, public), in type and level of activity (service giving, manufacturing and trade etc.) and location of the business organization. The researcher collects the intend data from different companies and Business organization like: - Hotel, Shop, and Mettu inland revenue authority. Total sample sizes of 35 respondents are from employees of FIRA and small business owners.

\subsubsection{Data Processing, Analysis and Interpretation}

The researcher is collected different types of raw data and then process, and interpretation are there so that the intend outcome will be obtained. In addition, the collect data will be edit, classify, examine and correct. By using descriptive analysis, the data are further be process and analyze. Descriptive method of analysis is use because more qualitative data is collected. The data can describe by using table form, in percent and as well as the table and percents also summarize in words. Finally, the data are effectively process at, analyze and the interpretation is taken place. The data process and analyze will leads to the specific conclusion of the study. Depending on the interpretation, reasonable explanation of the value added tax and its impact on business enterprises are explain and finally the weakness is recommended.

\subsection{Budget and Time Constraints}

4.1 Budget Constraint. It is impossible to accomplish the study without allocating the necessary budget. The researcher faces different expenses. So, in order to accomplish the study, the researcher plan the following financial budget.

Table 4.0. Budget Constraints

\begin{tabular}{|l|l|l|l|l|}
\hline S.NO & Types of Quantity & Quantity in amount & Price(P) & Total cost(Birr) \\
\hline 1 & Stationary material & & 480 & 480 \\
\hline 2 & Food & - & 400 & 400 \\
\hline 3 & Print & 100 & 5 & 500 \\
\hline 4 & Tea and Coffee & 100 & 2 & 200 \\
\hline 5 & Transport cost to collect data & - & 3 & 300 \\
\hline 6 & Use of internet & - & 150 & 150 \\
\hline Total cost & - & - & - & 2030 \\
\hline
\end{tabular}

Source: Primary data.

\subsection{Result Analysis and Discussion}

The findings of the study are based up on the analysis and discussion of the responses of the owners of the business enterprises and their employee in Bedele In order to make easy and understandable interpretation and inferences were made by comparing type of ownership (private or public) and type of business (service, manufacturing, trade etc) with their opinion towards the VAT system. As depending on the Source information obtained from the respondents, most of the business people found in the town are not registered for VAT. In addition to this it is important to see the different characteristics of sample population. These variables include types of business, types of ownership, and their registration time important to see the different characteristics or the sample population. These variables include types of business, type's ownership, and their registration time.

Table 4.1. Show sample size of the respondents

\begin{tabular}{|c|c|c|c|c|c|}
\hline \multirow[t]{2}{*}{ Type of business } & \multicolumn{2}{|c|}{ Private } & \multicolumn{2}{|c|}{ Public } & \multirow[t]{2}{*}{ Total } \\
\hline & Number & Percent & Number & Percent & \\
\hline Manufacturing & 0 & 0 & 0 & 0 & 0 \\
\hline Trade & 9 & 25.7 & 0 & 0 & $9(25.7 \%)$ \\
\hline Service & 10 & 28.6 & 12 & 34.28 & $22(62.88 \%)$ \\
\hline Other & 1 & 2.86 & 3 & 8.57 & $4(10.83 \%)$ \\
\hline Total & 20 & 57.16 & 15 & 42.84 & $35(100 \%)$ \\
\hline Total sample & \multicolumn{5}{|c|}{35 respondents } \\
\hline
\end{tabular}

Source: primary data. 
Financial Markets, Institutions and Risks, Volume 3, Issue 4, 2019

ISSN (online) - 2521-1242 ISSN (print) - 2521-1250

As the table 4.1 shows private and public sector contribute $57.16 \%$ and $42.84 \%$ of the targeted Population respectively the above figure reflects the number. Of private sector was more than the number of public sectors was more than the number of public sectors. This shows the study much of the problem was for private sector than problems for public sector.

Generally, services companies cover $62.88 \%$ of the total targeted population that was 35 . This was due to the fact that VAT was more applicable to it and affects service companies.

Relatively trading companies covers $25.7 \%$ of the targeted population and other type of business only $10.83 \%$ As stated in the methodology part, the total targeted population was 40 which were as actually filled by the respondent was 35 . However, the above fact shows that value' added tax was more applicable to service giving companies, this was because most of the businesses enterprises in the town was service giving. Depending on the view of the town's finance manger may business enterprises found in the town are not registered for VAT whose gross annual turnover are more than 500,000 birrs. This was due to the lack of Awareness that was given to them from FIRA. Due to this problem most of the business sectors in the town are not awarded about the tax system specially VAT system.

Table 4.2. Comparison of VAT collected, with number of registered people

\begin{tabular}{|l|c|c|c|c|}
\hline \multirow{2}{*}{ Types } & \multicolumn{2}{c|}{ Registration } & \multicolumn{2}{c|}{ VAT collection } \\
\cline { 2 - 5 } & No & Percent & 20 & 3 \\
\hline Public enterprise & 5 & 80 & 7 & 70 \\
\hline Private & 20 & 100 & 10 & 70 \\
\hline Total & 25 & 100 & \\
\hline
\end{tabular}

Source: primary data.

As indicated in the above table $80 \%$ of taxpayers were private sectors where as $20 \%$ of them were public enterprises. Grossly seen that 80 percent of the enterprises that is found in the town are liable for VAT is private sectors the remain $20 \%$ is public enterprises.

The second column illustrated that 3 million Birr (30\%) was collected from public enterprises and 7 million birrs $(70 \%)$ were collected from private sectors. Grossly seen most of VAT is collected from private sectors which increase government revenue.

Table 4.3. The view of targeted population that support the threshold (> 500,000 birr) is good or not good)

\begin{tabular}{|c|c|c|c|c|}
\hline \multirow{2}{*}{ Types business } & \multicolumn{2}{|c|}{ Number of respondent and their response } & not good \\
\cline { 2 - 5 } & Good & Percent & 34.29 & 1 \\
\hline Public & 12 & 51.43 & 4 \\
\hline Private & 18 & 85.72 & 11.42 & 5 \\
\hline Total & 30 & & 14.28 \\
\hline
\end{tabular}

Source: primary data.

As indicated in the above table $85.72 \%$ of the respondents' support the threshold $(>500,000$ birr) was good whereas the reaming $14.28 \%$ of the total population are the supporter of the threshold $(>500,000$ birr) was not good. This shows most of the business sectors annual turnover was less than 500, 000 birr. If threshold (500, 000 birr) and registered for VAT tax many business sectors are affected by VAT. To avoid such type of problem registration of dealers with gross annual turnover above 500, 000 birr will be Compulsory. All existing dealers will be allowed 30 days time from the date of liability to get registered. Small Dealers with gross annual turnover not. exceeding 500,000 will not be liable to pay VAT.

Table 4.4. The tax rate (15\%) accepted or not accepted by different business sector in the town

\begin{tabular}{|l|c|c|c|c|c|c|}
\hline \multirow{2}{*}{ Types of business } & \multicolumn{5}{|c|}{ Respondent's view about 15\% tax rate } \\
\cline { 2 - 7 } & High & Percent & Medium & Percent & Low & Percent \\
\hline Public sector & 16 & 45.73 & 1 & 2.85 & 0 & 0 \\
\hline Private sector & 17 & 48.57 & 1 & 2.85 & 0 \\
\hline Total & 33 & 94.28 & 2 & 5.7 & 0 \\
\hline
\end{tabular}

Source: primary data.

The above table indicates that from the total sample size 45.73 percent of public enterprise supports the idea that 15 percent tax rate was high whereas 48.57 percent of private sector have the same idea with the public enterprises. Only 2.85 percent of public enterprises and 2.85 percent of the private sector support 15 percent tax rate is medium. Nobody says 15 percent tax rate is low. Generally seen 94.28 percent of public and private sector do not support the idea of VAT with 15 percent tax rate. 
Table 4.5. The relationship between ownership and their registration time

\begin{tabular}{|l|c|c|c|c|c|c|c|c|c|}
\hline $\begin{array}{l}\text { Type } \\
\text { business }\end{array}$ & \multicolumn{2}{|l|}{ During implementation } & \multicolumn{2}{|c|}{$\begin{array}{l}\text { month after } \\
\text { implementation }\end{array}$} & \multicolumn{2}{l|}{$\begin{array}{l}\text { month } \\
\text { implementation }\end{array}$} & \multicolumn{2}{l|}{ Total } \\
\hline & No & $\%$ & No & $\%$ & No & $\%$ & No & $\%$ & No \\
\hline Public & 10 & 28.57 & 4 & 11.43 & 2 & 5.71 & 3 & 8.57 & 19 \\
\hline Private & 3 & 8.57 & 3 & 8.57 & 2 & 5.71 & 8 & 22.86 & 16 \\
\hline Total & 13 & 37.14 & 7 & 20 & 4 & 11.42 & 11 & 31.44 & 35 \\
\hline
\end{tabular}

Source: Primary data.

Table 4.5 shows 28.57 percent of public sector registered during the first month of implementation of VAT, only 8.57 percent of private sector registered at that time. $22.86 \%$ of private sector and only $8.57 \%$ of public sector registered currently. $5.71 \%$ of private sector and $5.71 \%$ of public sector register 6 months after implementation of VAT. In addition to this $11.42 \%$ of public sector and 8.57 and privet sector registers 3 months after implementation. The above result shows that public owned enterprises were registered during the first month of implementation of VAT. Whereas only private owned enterprises registered currently. These two facts show that private sectors will hide the financial statements and their annual sales not to be registered for VAT, while public owned enterprise may not hide their financial statement. This was because most of public owned sectors have not any rivalry. So, publishing or disclosing their financial statement may not affects their financial activity. During 2004 G.C in Addis Ababa under door to door assessment made by FIRA and police, nearly 400 business people become VAT eligible that means they have annual sales of $>500,000$ birr and 10 of the registered sectors performed illegal activities, (The Ethiopian Herald, 1996). These shows that eligible companies were not register fully. If there are 400 business people who are not registered under one day inspection there may be some more business people not registered. In Bedele town the above problem is also determined. That is many business sectors in the town are not registered for VAT. According to information the researcher got from the town's finance office any business people whose annual sale is $>$ 500,000 birr was not registered for VAT. The factors not to register on time are:

* Lack of strong and immediate rule to force them.

* Lack of awareness about tax system.

* Aiming to get huge profit without paying the appropriate tax etc.

Generally, FIRA did not registered most business whose annual sale was $>500,000$ birr. This makes reduction in revenues. So, it was one of the major problems of FIRA.

Table 4.6: respondents view towards the impact of VAT on customers and its recording problem

\begin{tabular}{|l|c|c|c|c|c|c|c|c|}
\hline \multirow{2}{*}{ Type of Business } & \multicolumn{3}{|c|}{ Respondents view on problem of recording } & \multicolumn{4}{c|}{ Number of customers } \\
\cline { 2 - 8 } & \multicolumn{2}{|c|}{ Yes } & \multicolumn{2}{|c|}{ No } & \multicolumn{3}{|c|}{ Increase } & \multicolumn{2}{|c|}{ Decrease } \\
\hline & No & Percent & No & Percent & No & Percent & No & percent \\
\hline Private & 14 & 40 & 3 & 8.57 & 0 & 0 & 20 & 57.14 \\
\hline Public & 16 & 45.71 & 2 & 5.71 & 0 & 0 & 15 & 42.86 \\
\hline Total & 30 & 85.71 & 5 & 14.28 & 0 & 0 & 35 & 100 \\
\hline
\end{tabular}

Source: Primary data.

Table: 4.6 Shows that 45.71 percent of public sector and $40 \%$ of private sector replied that VAT creates recording problem. Only 8.57 percent of private and 5.71 percent of public sector respondents replied that it does not create any recording problem. When we see it effect on number of customers, $57.14 \%$ of private respondent and 42.86 percent of public sector respondents replied that after implementation of VAT the number of customers decreases.

Generally seen, 85.71 percent of total targeted population answer that VAT creates recording problem. The reaming 14.28 percent do not agree on it. $100 \%$ of the total population replied that implementation of VAT decreases their customer. Therefore, customer shifting for one business to another is the problem of VAT registered business enterprises in the town.

The above result show that the tax system created an accounting and recording problem. In addition to this the number of their customers decreases after registration for VAT. This was due to the fact that FIRA were not teaching how to maintain VAT records. And the number of customers decreases due to the fact that customer did not understand the advantages of the tax system so they shift to non-VAT paid sectors.

In case of shifting customers, they will go to unregistered sectors to purchase items at fewer prices. But if all were registered, customers will not shift since any where there was $15 \%$ of VAT. It also might be due to lack 
Financial Markets, Institutions and Risks, Volume 3, Issue 4, 2019

ISSN (online) - 2521-1242 ISSN (print) - 2521-1250

of knowledge that VAT will increase price of item. Actually, there may be small amount of change as compared to sales tax, but individuals should understand the benefit of VAT overall economy.

Generally seen the tax system was creating an accounting problem and shift the customers to unregistered one. So, this was one of the limitations of the tax administers.

Table 4.7. The view of targeted population on VAT and its effect on sale

\begin{tabular}{|l|c|c|}
\hline \multirow{2}{*}{ Responses } & Respondents number and percentage about VAT and affection sale \\
\cline { 2 - 3 } & No & Percent \\
\hline Yes & 30 & 85.71 \\
\hline No & 5 & 14.29 \\
\hline Total & 35 & 100 \\
\hline
\end{tabular}

Source: primary data.

Table 4.7 explained that from the total targeted population $85.71 \%$ of them say that $\mathrm{V}$ A $\mathrm{T}$ have effect on sale and only 14.29 percent of them support the idea that V A T has no impact on sale.

According to the above information' and the researchers got information by interviewing' the respondents VAT have impact on sale) that means VAT adds price on customers. All of the business people that pay VAT are added the amount of VAT to the price of commodity they sale. During this time the price of commodity increases, and it makes the shifting or customers to non-VAT payers.

Generally, the above Information shows that all VAT payer business sectors didn't sale their commodities as non-VAT payer, because VAT was additional price for customers of VAT payers. The increase and VAT on p rice of commodity makes most of VAT payers in the town turn back their VAT registration slip to FIRA's office, in such manner the above problem makes decrease in government revenue.

Table 4.8. Respondents Idea about implementation of VAT was good but the Tax system complex

\begin{tabular}{|c|c|c|c|c|}
\hline \multirow[t]{2}{*}{ Attitude measurement } & \multicolumn{2}{|c|}{ VAT is advantageous for my business } & \multicolumn{2}{|c|}{ Tax system seems complex } \\
\hline & No & Percent & No & Percent \\
\hline Strongly agree & 2 & 5.71 & 12 & 34.29 \\
\hline Agree & 4 & 11.43 & 16 & 45.71 \\
\hline Disagree & 25 & 71.43 & 5 & 14.29 \\
\hline I don't know & 4 & 11.43 & 2 & 5.71 \\
\hline Total & 35 & 100 & 35 & 100 \\
\hline
\end{tabular}

Source: primary data.

Table 4.8 shows $71.43 \%$ of the target total populations do not accept the idea that VAT is advantageous for my business. $5.71 \%$ and $11.43 \%$ of them strongly agree and agree respectively on it. When we see their attitudes towards its complexion $45.71 \%$ of them agree and $34.29 \%$ of them are strongly agree. Only $14.29 \%$ of them disagree on the above idea. The remaining 5.71\% reply I do not know. The above result explains that all in all tax, administrator was not given enough awareness forth business people in the town. This awareness would not been created before implementation of tax system; Even, after implementation employee and tax payers were not award about the tax system. That was why tax payers were; not, advantageous and it increases price of commodity. They also' not identify items that are free from VAT and they do not have enough knowledge how to maintain recorded. Whereas the tax authority announces that as it creates enough, awareness to them. Value added tax was a complex system than other tax, systems. It was difficult to implement the whole concept once, but users should know basic principles. It was also clearly indicated on the second result. Most of the respondent's 71.43 percent disagree on the idea that YA T was advantageous for their business whereas the reality was that VAT will be advantageous for individual business and society as a whole if it was implemented properly and effectively"

\subsection{Summary of Findings, Conclusions and Recommendation}

5.1. Summary of the findings. The study is conducted to analysis the impact of value added tax on the business such as public or private owned enterprises found at Bedele town and weakness of tax administer in the town. The problems were identified form the respondents replay, and researchers own observations.

* This shows public companies are not registered on preferred manner but pay expected amount when compared with the registered private companies. The above result shows private companies are reregistered more than public enterprises, but private companies were. Not paying expected amount of V AT. 
Financial Markets, Institutions and Risks, Volume 3, Issue 4, 2019 ISSN (online) - 2521-1242 ISSN (print) - 2521-1250

* The result also showed that the yearly turnovers of the business are the main factor that should be considered to collect value added tax. As indicated in the analysis part $85,72 \%$ of the respondents support the threshold (>500,00 birr) was good whereas only 14.28 says not good. (Table 4,3).

* As the result indicates that most of the enterprises whose yearly turnover is more than 500,000 birrs was not' registered' to value added tax, this indicates the' backwardness of the in-land revenue authority. (or tax administer).

* FIRA is unable to fulfill necessary facility administration, of VAT system in the town, 'In addition to this there was also recording problems,' unable to register eligible companies, absence of certainty in the law and the like are the major problems found in the town. Most of the above problems exist due to lack of awareness among society and are the problems of FIRA. It is more discussed one by one in the result analysis discussion part.

* $\quad 94.28 \%$ of the total populations are not agreeing about the idea of. $15 \%$ tax rate. They say that $15 \%$ rate is high. Only $5.72 \%$ responded the rate is medium. Nobody says I $5 \%$ rate is good.

* $\quad 97.6 \%$ of the total population replied that implementation of VAT decreases customers. This makes shifting of customers form one business to another business or shifting of customers form registered to nonregistered companies. This was one of the limitations of tax administers.

* Most of the respondents say that VAT has negative impact on. That was it increase price of commodity. As explained above this creates shifting of customers.

* Customers are shifted from registered companies to non-registered companies this make reduction is government revenue. The inability of FIRA to register the eligible companies is one of FIRA's problem

* Negative impact on customer: VAT increases price of commodities; it means that customer of VAT registered enterprises pays the amount of VAT calculated in addition to price of commodity. This may make the unsatisfaction of customers on the product they bought. In addition to this customers payment of VAT in addition to cost of good will result in decrease in customer capital without any benefit. This makes shifting of customers form registered enterprises to unregistered enterprises.

* Lack of awareness: It was clear that most taxpayers did not have enough knowledge about the system. Even employees of FIRA have not enough awareness on most tax items. Due to this many cheques and receipts become void. This will have high stationery cost. And they try to collect VAT for non-taxable items and not collect VAT on taxable item. This will result discouraging their customers and decreasing government revenue

* Eligible companies were not register fully: As it was shown on the Table form 35 people (sample Size) 31 of them say that. Eligible companies were not register. If all eligible companies not registered, the registered companies will be affected or will not be competitive. And due to this governments revenue from VAT will decrease. So, this is also another sever problem on the system.

* Lack of certainty in the law: The proclamation number 285/2002 was "not strong and not implemented effectively. According to the proclamation not registration for VAT while they are eligible was illegal and has punishment. But FIRA was not punishing them. If they are not punished, others try to perform this illegal duty.

5.2 Lack of appropriate record: Most business people have not clear, fair and true records. Due to this it was impossible to identify the exact amount of VAT collected.

\section{Conclusion}

The study basically was intended to analyze the impact of VAT on the business enterprises. The study aims at identifying on what why and how the business was affected by this tax. Most business people do not support or accept the tax rate. They replied that the tax rate should decrease. In addition to this FIRA tries to create awareness about tax payer's but it was not enough and not considered the society. FIRA considered only the tax payer. Private sector business plays great contribution for VAT most of the business people don't agree with the threshold $(>500,000)$. This wasbecause of the availability of most of the business sectors to be illegible for Vat if it was less than that except small percentage, more of the people literature that can read and write. Most of the people that are found in the town do have any knowledge about the system of value added tax. Due to different reasons attitude of the society towards the tax system is negative. This was due to lack of knowledge about its use. They thought as it has negative impact on number of customers, and it creates obstacle during competition. In addition to this people think that VAT reduces income of the business. Even if the study 
Financial Markets, Institutions and Risks, Volume 3, Issue 4, 2019

ISSN (online) - 2521-1242 ISSN (print) - 2521-1250

has the above shortcomings, it was important for further studies in related topics: Further studies that try to conduct more rigorous investigation to determine the impact of VAT on the business enterprises can make use" of the result of the study.

5.3. Recommendations. The study which aims at identifying impact of value added tax on business was generally helpful in having some images about the shortcoming. Of VAT system and need further recommendation from the researcher. The federal Inland Revenue authority has given less care for clear and feasible way of the taxation system that was practice among business enterprises at large publishing newspapers and distribution not only at Addis Ababa (Finfine) but also throughout the country, establishing discussion for to successfully implement and to insure acceptability of the above information certain factors should be considered. Such factors are included perdical workshop, communication and using media to increase the knowledge of people about tax.

A. Workshop: At the beginning weekly or monthly workshop should be given to individual to establish basic stone form increasing the knowledge of importance of advantage of taxes. After that the responsible body may elongate to the workshops to a year or discontinue according to the need. This is one of an easy way to increase the knowledge of people about tax.

B. Using media: As such as possible the Inland Revenue authority should use a media and communicate with its customers (payers) about the system of taxation and grade up their knowledge.

C. Using magazines: The FIRA should prepare some magazines that reflect the importance and the passiveness of tax.

The tax administer should undertake unexpected checking of accounts of business, to control correct amount of V AT collected. The tax rate should be reduced and differentiated for luxury good and necessity goods. In addition to this FIRA should revise tax policy and discuss with society and trade unions like chamber of commerce. Implementation of hard and fast rule should be done effectively to reduce illegal activities of some business people in the town. To do this in a right manner all of the registered business people must display their certificate in a clear and visible place. To solve the problems of accounting and recording, FIRA should trait employee of VAT payer business enterprises. FIRA should develop software to record VAT, if the economy is allowed. Each taxable item will be coded in the computer. During the time of sale employee will feed the code of the item, immediately the item and the VAT amount and total price will be displayed.

\section{References}

1. Alan Shenckand Oliver Oldman. (2001). Value Added Tax: A comparative approach with material and cases. Transnational Publishers, NHBS.

2. Arega Hailu. (2004). Assessment on value added Tax implementation in Ethiopian. A paper presented on the second international conference on the Ethiopian economy.

3. Cottarelli, C. (IMF, March 2011). International Monitory Fund Executive Board Discussion on Revenue Mobilization in Developing Countries, Prepared by the Fiscal Affairs Department.U.S.A

4. Dr.Ramaswami Parameswaran (2005). Public Finance And Taxation, Departments of Accounting and finance, Addis Ababa University, Addis Ababa, Ethiopia .

5. Gebru Worku (2006). Tax Accounting in Ethiopia context. (1st edn). Addis Ababa University; College of Commerce.

6. Gberie Worku (2008). Tax Accounting in Ethiopia context. (2nd edn). Lanning; MI USA.

7. H.L Bhatia. (1998). Public Finance (23rd revised editions). Vikas Publishing House Pvt Ltd.

8. Misrak Tesfaye (2008). Ethiopia Tax Accounting; Theory and Practice. (1st edn) Research and Publication UUC.

9. Gupta Alka. (2001). Public Finance and Tax Planning. Anmol Publications Pvt. Ltd. New Delhi

10. Negarit Gazeta (2002). Value Added Tax Proclamation. No 285/2002, Addis Ababa, Ethiopia.

11. . Omokhuale and Immanuella 2016. Evaluation of the contribution of VAT to the Nigeriall Economy. EPRA International Journal Economic and Business Review, 4 (2), 82-97.

12. The Ethiopian Herald, Local News Agency. (1996). Addis Ababa, Ethiopia, 60, 174.

13. Yohannes Mesfen and Sisay Bogale (2009), Tax law, Teaching materials prepared under the Sponsorship of the Justice and Legal System. Research Institute. 
14. Zerihun, W. (2016). The Strong Growth of Ethiopian Economy. African. Economic Outlook organization. Retrieved from: com a.zerihun@afdb.org.

15. Gebrie Worku. (2008). Tax accounting in Ethiopia 2nd ed. Addis Ababa Alem printing press.

16. Bird, R.M. (2005). Value added taxes in developing and transitional countries: Lessons and questions', ITP Paper No. 0505, International Tax Program, Rotman School of Management, University of Toronto, available at: http://www.rotman.utoronto.ca/iib/ITP0505.pdf>, accessed November 2007.

17. Bird, R.M. and P-P Gendron. (2005). VAT revisited: A new look at the value added tax in developing and transitional countries', paper presented at the USAID Workshop for Practitioner on Tax, 4 May.

18. CIA 2007, World Fact Book Ethiopia. (last updated 18 October 18 2007). Available at <https://www.cia.gov/library/publications/the-world-factbook/geos/et.html\#Econ>, accessed October 2007.

19. Ethiopian Delegates. (2006). Value added tax in Ethiopia, Speech at the 9th Value Added Tax Administration in Africa (VADA) Forum, Zimbabwe.

20. FDRE. (2002). Value Added Tax Proclamation No. 285/2002', Federal Negarit Gazeta, Addis Ababa, Ethiopia.

21. Jantscher, M. Casanegra. (1990). Administering the VAT' in M. Gillis, C.S. Shoup and G.P. Sicat (eds) Value Added Taxation in Developing Countries, World Bank, Washington DC.

22. McLure, C.E. (2000). Implementing sub-national value added taxes on internal trade: The Compensating VAT (CVAT), Journal of International Tax and Public Finance, 7(6), 723-740.

23. Teffera, A.H. (2004). Assessment on the value added tax implementation in Ethiopia', Paper presented at the 2nd International Conference on the Ethiopian Economy, United Nations Conference Centre, Addis Ababa, 3-5 June.

24. Vehorn, C.L. and J. Bondolo. (1999). Organizational options for tax administration', Bulletin for International Fiscal Documentation, 53(11), 499-512.

25. Yesegat, W. A. (2008). Estimating VAT administrative costs in Ethiopia', Paper presented at the 8th International Conference on Tax Administration, Atax, Sydney, 27 -28 March.

26. Council of Ministers - Federal Democratic Republic of Ethiopia. (2002). Value Added Tax Regulation, Council of Ministers Regulation No. 79/2002', Federal Negarit Gazeta, Addis Ababa, Ethiopia. 